\title{
Taxing Capital Protected Equity Products
}

\section{Christine Brown and Kevin Davis}

C apital Protected Equity Products (CPEPs), described in detail in the following section, have become a popular financial product in Australia in recent years. They package together, for retail investors, a loan for stock market investment and protection against exposure to losses in the capital value of that investment. The investor incurs costs reflecting interest on the loan, 'facility' fees, and protection costs (typically aggregated and described as interest costs), and has the benefit of share ownership financed by borrowing and protection against capital loss. One reason for the popularity of such products has been the opportunity they provide to invest in shares paying franked dividends, while claiming interest expenses on the funds borrowed as tax deductions.

Because the costs of the CPEP are not separately identified, CPEPs have provided (despite the efforts of the Australian Tax Office) the opportunity for investors to exploit inconsistencies in the tax treatment of complex financial products arising from differences in the tax treatment of ordinary income (and expenses) and capital gains (and losses). A Federal Court of Australia (2002) ruling in Firth v Commissioner of Taxation meant that all of the costs of a CPEP to the investor could be treated as an expense for tax purposes, despite some part of that cost being, in effect, a capital item.

In April 2003, the Federal Government announced that an interim approach would be put in place for the tax treatment of CPEPs, pending an amendment to the law (Australian Treasurer, 2003). Details of the interim approach were announced in May 2003 (Assistant Australian Treasurer, 2003). At the time of writing (mid 2005) consultations between public sector officials and the finance industry on a replacement approach were underway.

This paper contributes to the public debate on the appropriate tax treatment of such products (see Boadway and Keen, 2003 for a general analysis of alternative taxation treatments of complex financial instruments). It is argued that finance theory (and the basic structure of Australian tax law) implies the following:

- The 'quoted' interest, or total, cost of a CPEP should be split into: (a) a 'pure' interest component; (b) a 'facility' cost for marketing and operating costs and profit of the CPEP provider; and (c) a payment for capital protection.

- The tax treatment of the three components should be as follows:

'pure' interest cost should be deductible by an investor as an expense;

Christine Brown is Associate Professor in the Department of Finance at The University of Melbourne. Kevin Davis is Commonwealth Bank Group Chair of Finance, Department of Finance, The University of Melbourne and Director, Melbourne Centre for Financial Studies. 
facility costs could be treated as a deductible expense or a capital cost; and payment for capital protection should be treated as a capital transaction and dealt with under the capital gains provisions.

- The allocation of the total cost of a CPEP charged by the provider between the three components involves calculating one component as a residual item. Either the cost of capital protection (component c) can be derived by subtracting estimates of a (the pure interest cost) and $b$ (the facility cost) from the total cost, or component b can be derived by subtracting estimates of a and c from the total cost of the CPEP. Since finance theory enables more accurate estimates to be made of components a and c than can be made of component $\mathrm{b}$, the latter approach is recommended.

- The 'pure' interest cost should equal a risk free interest rate (or one reflecting the CPEP provider's credit rating) if the facility provides 100 per cent capital protection. (As explained later, in this case 'default risk' is equivalent to the market risk associated with the protection component and should not be double counted.) As the level of capital protection declines below 100 per cent, the 'pure' interest cost should allow for an increasing 'credit spread' to reflect default risk faced by the CPEP provider. However, the credit spread should be significantly less than that for unsecured personal lending.

- The 'capital protection' component of any CPEP cost can be calculated directly and easily (albeit subject to some margin of estimation error), using generally accepted principles of finance theory. The size of this component cost will depend upon the level and period of protection as well as upon characteristics of the share portfolio involved. It will thus be different for different CPEPs. Since it is inconceivable that any provider of CPEPs would not have estimated the cost of such capital protection, there seems little reason not to use such estimates directly (subject to some verification process) in allocating the total cost of the CPEP between its components. Indeed, it might be argued, on investor protection grounds, that investors in such products should be informed in the product prospectus about the market value of capital protection inherent in the product.

- The interim approach currently used by the ATO to allocate total costs of a CPEP between interest expense and capital protection costs underestimates the protection cost component. The degree of underestimation is substantial and means that CPEPs receive favourable tax treatment.

The paper is structured as follows. The next section provides an overview of the characteristics of CPEPs. The correspondence between the non-recourse loan feature of CPEPs and put options is established in the following section. This enables an analysis of how to calculate the 'pure' interest rate appropriate to CPEPs in the third section. We then consider the fundamentals of the tax treatment of CPEPs and the fifth section examines the interim approach adopted by the Australian Government since 2003. The final section considers complications for tax treatment arising from legal and practical considerations and concludes with recommendations for policy. 


\section{Capital Protected Equity Products: An Overview}

CPEPs are of two broad types. One group of products are exchange traded products such as Instalment Warrants. These involve the investor outlaying funds (a first instalment) perhaps equal to around 50 per cent of the underlying share price to purchase the warrant. The underlying share is purchased and held in trust for the investor by the warrant issuer using the first instalment and loan funds provided by the warrant issuer. By repaying the loan amount (and interest) by making the second instalment, the investor gets clear title to the share. If the share value is less than the second instalment amount, the investor can put the share to the warrant issuer for an amount equal to the second instalment amount, thereby avoiding losses greater than the amount of the first instalment. Over the life of the warrant, the investor receives the dividends paid on the share.

The second group of products, which are the focus of this paper, are schemes offered by banks (or other financiers). They provide an investor with a facility to borrow money, for a specified time such as 3 years, to be invested in a specified share portfolio and incorporate features which protect the investor against a fall in the market value of those shares. Generally, the protection arises because the facilities are marketed as involving a loan with 'no-recourse' or 'limited-recourse'. In such loans the bank has no claim against an individual that defaults on repayment. However, the bank has security in the form of a mortgage on the share portfolio in the event of default by the borrower. Thus, if the value of the share portfolio is below the loan amount outstanding at the maturity of the loan agreement, the borrower can default on the loan and surrender the shares to the bank. If the value of the share portfolio is above the loan amount outstanding, the borrower will repay the loan and have benefited from the higher share value. Typically, such facilities involve 'interest only' repayments, such that no capital payments are made prior to maturity, when the loan amount to be repaid equals the amount initially lent. Wetspac's PEL Plus is an example of such a product ${ }^{1}$ (see also ATO, 2005a,b).

Table 1 illustrates the cash flows (exclusive of tax considerations and dividends received on the shares) for an investor using such a product, where the specified interest rate on the loan is $\mathrm{r}$ per cent p.a. The amount borrowed at date 0 (and initial share portfolio value) is $S_{0}$, and the term is three years. In this hypothetical example, there are no other fees or charges, and interest is paid annually in advance. (Interest in advance is typical, and means that the effective annual interest rate is much higher). The table shows the date 3 contingent cash flows which depend upon whether the share portfolio value at that date $\left(S_{3}\right)$ is above or below the initial value $\left(\mathrm{S}_{0}\right)$.

As can be seen from Table 1, the investor makes 'interest payments' over the term of the loan, and in return has no exposure to a decline in the share portfolio value below $S_{0}$, but benefits if the share portfolio value increases above $S_{0}$. It is

1 https://www.westpac.com.au/internet/publish.nsf/AttachmentsByTitle/FSR_Protected EquityLoanPlusPDS.pdf/\$FILE/FSR_ProtectedEquityLoanPlusPDS.pdf 
also implicit in Table 1 that the bank suffers a loss at date 3 of $\left(\mathrm{S}_{0}-\mathrm{S}_{3}\right)$ if the investor defaults, and that exposure will not be taken on by the bank without some compensation. In this example, that compensation comes from a loan interest rate (r) higher than the 'usual' interest rate required to compensate for customer default risk. The interest rate thus incorporates something akin to an insurance premium (for protection against declines in the share portfolio value) as well as a 'pure' borrowing cost. In practice, as discussed later, the bank will calculate that implicit insurance premium by reference to the costs it incurs in removing the exposure to loss by transactions in financial markets (such as purchasing a put option over the share portfolio). It should also be noted that the interest rate (and any explicit fees) charged by the bank will need to cover operating costs associated with providing the product, and will involve a profit margin which will depend upon the degree of competition and nature of customer demand in this market.

Table 1: Hypothetical Protected Equity Loan Product: Cash flows

\begin{tabular}{l|ccccc}
\hline & Year 0 & Year 1 & Year 2 & \multicolumn{2}{c}{ Year 3 } \\
\hline & & & & $S_{3}<S_{0}$ & $S_{3}>S_{0}$ \\
& & & & Default on loan & Repay loan \\
Loan principal & $+\mathrm{S}_{0}$ & & & 0 & $-\mathrm{S}_{0}$ \\
Interest & $-\mathrm{rS}_{0}$ & $-\mathrm{rS}_{0}$ & $-\mathrm{rS}_{0}$ & & \\
Share Portfolio & $-\mathrm{S}_{0}$ & & & 0 & $\mathrm{~S}_{3}$ \\
Net cash flow & $-\mathrm{rS}_{0}$ & $-\mathrm{rS}_{0}$ & $-\mathrm{rS}_{0}$ & 0 & $\mathrm{~S}_{3}-\mathrm{S}_{0}$ \\
\hline
\end{tabular}

There are many potential variants on such a structure, including the possibility of some up front fees and charges and some initial contribution to the purchase price of the share portfolio by the investor, such that the loan amount is for less than $S_{0}$. (This is the case in an Instalment Warrant). In some cases, such as Westpac's PEL Plus, capital protection may apply individually to each share in the portfolio, rather than at the aggregate level.

It is also possible that the facility is structured to provide only partial 'protection' to the portfolio. For example, a bank may lend the borrower the full purchase price $S_{0}$, provide capital protection at a lower level $S^{*}<S_{0}$, and have recourse to the borrower for a repayment amount up to some value $S_{0}-S^{*}$.

\section{Non-recourse loans and put options}

Capital protected equity products, such as described above, involve use of limited or non-recourse loans secured by the share portfolio. While the bank has no claim on the defaulting borrower (unlike the case of a 'full recourse' loan), it has a mortgage over, and recoups, the share portfolio in the event of default. Although legal interpretations may (unfortunately) differ, from a finance perspective this type of arrangement is equivalent to one based on the investor having received a put option over the share portfolio from the bank. Such an option gives the investor the right (but not the obligation) to sell (put) the share portfolio to the 
bank at some future date for an amount (the exercise price) specified in the option contract regardless of the market value of the portfolio at that future date.

Ignoring, temporarily, the interest payments involved, the example described in Table 1 is equivalent to an investor having received a 'full recourse' loan (with interest paid in advance) to purchase the share portfolio, and obtained an option to put that portfolio to the bank at date 3 at an exercise price of $S_{0}$. If the portfolio value is below $S_{0}$ at date 3 , such an investor will exercise the option, selling the shares to the bank for $S_{0}$ and use these proceeds to repay the loan. If the portfolio value is above $S_{0}$, the investor will not exercise the option and will repay the loan for a net gain of $S_{3}-S_{0}$. The cash flows at date 3 (and all prior dates) are thus exactly the same as in the case of the 'no recourse' loan.

Interpreting the CPEP as a 'full recourse' loan and receipt of a put option implies that the investor makes 'pure' interest payments on the loan plus a payment for the put option received, which together correspond to the interest charged in the 'non-recourse' loan approach. The relative magnitude of these two implicit components can thus be determined.

Consider first the 'pure' interest component. From the bank's perspective, the loan is secured by the share portfolio, and by the put option held by the investor. (Note that for the loan officer determining an appropriate interest rate, it does not matter whether the put option was granted by the same bank or another institution of equal credit rating). Assuming no risk of the writer of the put option defaulting on the obligation, this implies that the minimum value of the security is $\mathrm{S}_{0}$ (the strike price of the put option). There is thus no credit (default) risk associated with the loan principal (and default risk on interest payments is removed by their payment in advance). The 'pure' interest rate charged on the loan should thus be the risk free rate of interest (or reflect the credit rating of the bank granting the put option to the investor if there is some risk that that bank will not honour its obligation).

The remainder of the 'interest payments' should equate to the value of the put option granted by the bank. Technically, the present value of the stream of interest payments in excess of the 'pure' interest amount, should equal the fair value of the option - which can be calculated using theoretical models of option prices such as the Black-Scholes (1973) formula. In practice, banks can be expected to charge more than the 'pure' interest rate plus fair value of the option. How much more will depend upon the competitiveness of the market for CPEPs, and the impediments to investors replicating such facilities by direct transactions in stock and options markets.

In the limited recourse case, where a bank has recourse to the borrower up to some amount $\mathrm{S}_{0}-\mathrm{S}^{*}$ the bank is exposed to credit risk arising from the possibility of non-payment of this amount. In this case, the interest charged on the facility effectively consists of three components: 'pure' interest on a risk free loan of $\mathrm{S}^{*}$; 'pure' interest on a risky loan of $\left(\mathrm{S}_{0}-\mathrm{S}^{*}\right)$; and the value of the put option granted. 


\section{Deriving the appropriate loan interest rate}

The relationship between the appropriate interest rate to charge on the nonrecourse loan and the put option value can be derived using an approach similar to Merton (1974). Consider the simple case where the investor promises to repay $\$ F$ in one year in return for funds received now (date 0 ) to buy a share portfolio with value $S$ and a put option with exercise price $K$ and value of $P$. Thus $\$ F=\$(S+P)(1+r)$ since $F$ incorporates interest on deferred payment for the put option as well as loan interest. Adopting the standard CPEP approach of quoting an interest rate (incorporating all costs) of $\mathrm{r}_{\mathrm{q}}$ on a borrowed amount of $\mathrm{S}$ such that

$$
\mathrm{SF}=\mathrm{S}\left(1+\mathrm{r}_{\mathrm{q}}\right) \text { it is easy to see that: } \quad\left(1+\mathrm{r}_{\mathrm{q}}\right) /(1+\mathrm{r})=\frac{S+P}{S}
$$

It is thus clear that $r_{q}$ incorporates the value of the put option. Based on well known option pricing relationships the effect of various parameters on the relationship between $r_{q}$ and the 'pure' interest rate ( $r$ ) can be derived. If $K$ exceeds F such that the borrower will always make repayments, then the pure interest rate in equation 1 should be the risk free interest rate. The quoted rate of interest will be higher relative to the 'pure' rate of interest for higher protection levels (K), more volatile stocks, and long term facilities.

What are the consequences for the 'pure' interest rate when the option exercise price $\mathrm{K}$ is less than the promised repayment of $\mathrm{F}$, such that there is some default risk associated with the facility? First, it is clear that there is no default risk on $\$ \mathrm{~K}$ of the promised repayment, which can be raised by exercising the put option. The default risk associated with the remaining $\$(\mathrm{~F}-\mathrm{K})$ of the promised repayment can only be assessed by considering the joint eventuality that the share portfolio value is below $\$ F$ and that the borrower defaults.

A worst-case scenario (from the bank's perspective) is to assume that the borrower defaults with certainty when the share portfolio value is between $\$ \mathrm{~K}$ and $\$ F$. In this case the payoff to the bank on the risky loan amount of $\$(F-K)$ is as shown in Figure 1. If the share portfolio value at maturity, $\mathrm{S}_{\mathrm{T}}$, is greater than $\mathrm{F}$ then the bank recoups the full amount. When $\mathrm{K}<\mathrm{S}_{\mathrm{T}}<\mathrm{F}$ the borrower defaults and the bank recoups $\mathrm{S}_{\mathrm{T}}-\mathrm{K}$, and for $\mathrm{S}_{\mathrm{T}}<\mathrm{K}$ the bank recoups 0 .

Technically, the payoff shown in Figure 1 is equivalent to that generated by purchase of a call option on the underlying stock with an exercise price of $K$ plus sale of a call option with an exercise price of $\mathrm{F}$. The amount advanced to the borrower for the loan with the risky payoff depicted in Figure 1 should just equal the cost of obtaining the identical payoff by transactions in the two call options. Consequently, it is possible to use option pricing theory to calculate the amount the lender would be willing to advance for promised repayment $\mathrm{F}-\mathrm{K}$ and the corresponding implied interest rate $\mathrm{R}$. Table 2 gives solutions for $\mathrm{R}$ for a range of protection levels, $x=K / F$, where $x$ is the proportion of the promised repayment $F$ protected by a put option with strike price $\mathrm{K}$. It also shows the quoted interest rate on the facility $\left(\mathrm{r}_{\mathrm{q}}\right)$ which is a weighted average of $\mathrm{R}$ charged on the unprotected part and the risk free rate (r) charged on the protected part. Table 2 assumes a risk 
free interest rate level of 5 per cent, share price volatility of 30 per cent, time to maturity of 3 years and a dividend yield on the share of 4.5 per cent p.a.

\section{Figure 1: Payoff on 'Full Recourse' Loan Component of $\$(F-K)$}

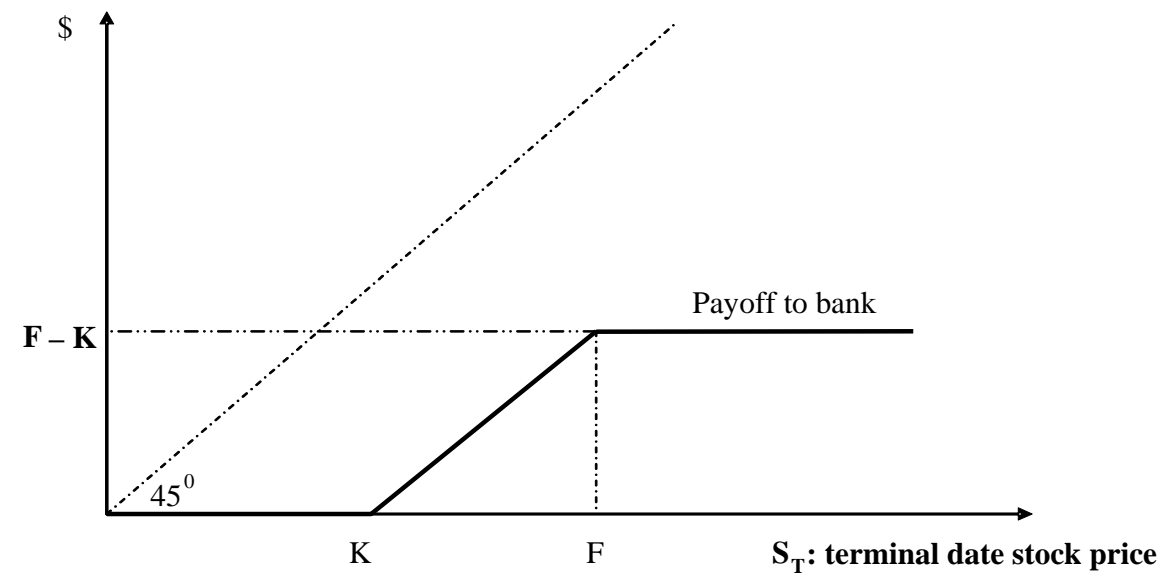

Table 2 is interpreted in the following way using the entries in the first column as an example. Assume the promised repayment is $\$ 100,000$. The bank's fair interest charge on the 30 per cent of the total loan that is unsecured is 26 per cent. The weighted average interest rate for this facility (with 70 per cent of the portfolio value protected) is 11 per cent, assuming that the risk-free rate is the appropriate rate for the promised repayment of $\$ 70,000$ (protected by the put with strike $\mathrm{K}=\$ 70,000)$.

\section{Table 2: CPEP: Illustrative Estimates of Appropriate Interest Cost}

\begin{tabular}{l|lllllll}
\hline $\mathrm{x}=\mathrm{K} / \mathrm{F}$ & 0.70 & 0.75 & 0.80 & 0.85 & 0.90 & 0.95 & 0.99 \\
$\mathrm{R}:$ interest rate on $\$(\mathrm{~F}-\mathrm{K})$ & 0.26 & 0.27 & 0.29 & 0.30 & 0.32 & 0.33 & 0.35 \\
$\mathrm{r}_{\mathrm{q}}$ : Weighted average interest rate & 0.11 & 0.11 & 0.10 & 0.09 & 0.08 & 0.06 & 0.05 \\
\hline
\end{tabular}

Assumptions: Risk-free rate $r=5$ per cent, volatility $\sigma=30$ per cent, time to maturity $\mathrm{T}=3$ years, dividend yield $\mathrm{d}=4.5$ per cent.

$R$ is calculated using $C(S, K, \sigma, r, T, d)-C(S, F, r, \sigma, T, d)=(F-K) e^{-R T}$

where $\mathrm{C}($.) represents the price of a call option.

Several comments are in order:

- We calculate the average weighted 'pure' interest rate for the full loan assuming that the 'pure' interest rate charged on the loan of \$K (covered by the put option) is the risk-free rate. 
- The 'pure' interest rates on the loan $\$(F-K)$ appear high, but the average weighted 'pure' interest rates on the total loan $\mathrm{F}$ are considerably lower, because the non-recourse portion is relatively high.

- The interest rates given in the table provide an upper bound because we have assumed that the borrower defaults with probability 1 when $\mathrm{K}<\mathrm{S}_{\mathrm{T}}<\mathrm{F}$. Assuming a more appropriate probability of default significantly reduces these figures. For a probability of default of $0<\mathrm{p}<1$, the interest rate charged on the full-recourse loan - of $\$(F-K)$ - should be close to the weighted average of the risk free rate and the figure derived in Table 2 and given by $\mathrm{R}^{*}=\mathrm{pR}+(1-\mathrm{p}) \mathrm{r}$. Taking the case of a protection level of 70 per cent $(\mathrm{x}=0.7)$ from Table 2 , and a probability of default of $\mathrm{p}=0.2$, gives $\mathrm{R}^{*}=0.2(0.26)+0.8(0.05)=0.092$. The weighted average interest rate for the full loan of $F$ then becomes $0.7(0.05)+0.3(0.092)=0.0626$ (6.26 per cent) rather than the figure of 0.11 shown in the first column of Table 2.

\section{Taxation and Capital Protected Equity Products}

The tax treatment of CPEPs in Australia has been complicated by the Federal Court ruling in 2002 (Firth $\mathrm{v}$ Commissioner of Taxation) that if no separate identification or valuation of the capital protection is made, the quoted interest is to be regarded as a deductible borrowing expense. Such a view ignores the functional equivalence between a share purchase facility involving a limited recourse loan and one involving a full recourse loan and put option.

This would be of little practical import if CPEPs were for terms of less than one year (such that there was no necessity to distinguish between capital gains and other forms of income for tax purposes) or if gains and losses on option positions held for more than one year were not treated under the capital gains tax provisions of the Tax Act. Neither of these conditions applies. CPEPs are generally for terms longer than one year. Under Australian tax law, the purchase price of an option is treated as a capital expense and the gain or loss on sale, exercise, or expiry of the option is treated as a capital gain or loss.

This tax treatment of options is open to question, since it is possible to interpret the option as equivalent to purchase of insurance against risk of changes in the price of the underlying item. It could thus be argued, for example, that the investor is hedging the risk associated with earning assessable income in the form of dividends on the shares purchased. Adopting this position would lead to amortising (according to some formula) the option premium paid over the life of the option to derive a stream of deductible expenses. If that approach were adopted, the necessity of dividing the quoted interest rate on a CPEP into 'pure' interest rate and option premium components would be unnecessary. (See Bradford (1997) for a more fundamental problem with the tax treatment of options arising from different tax treatment of the replicating portfolio.)

That, however, is not the case. Consequently, the Federal Court judgement would lead to a situation where the quoted interest is treated as a deductible expense whereas it is, in principle, a combination of a smaller interest amount 
(which should be a deductible expense) and the purchase price of a put option (which is treated under Australian tax law as a capital transaction).

It is possible to demonstrate the anomaly in the tax treatment of CPEPs relative to that of their components arising from the Federal Court judgement using a simple example. Consider the situation where at date 0 an individual has purchased shares for price $S_{0}$ and a put option (with exercise price $S_{0}$ ) for price $P_{0}$ and expiry at date T. This component of the CPEP is often referred to as a 'protective put'. Table 3 illustrates the capital gains tax consequences (assuming for simplicity that the shares are sold at date $\mathrm{T}$ ).

\section{Table 3: Protective Put Strategy: Capital Gains Tax Consequences}

\begin{tabular}{l|cc}
\hline & $\begin{array}{c}S_{T}<S_{0} \\
\text { Put option worth } S_{0}-S_{T} \text { and is } \\
\text { exercised }\end{array}$ & $\begin{array}{c}S_{T}>S_{0} \\
\text { Put option expires worthless }\end{array}$ \\
\hline Capital gain on shares & $\mathrm{S}_{\mathrm{T}}-\mathrm{S}_{0}<0$ & $\mathrm{~S}_{\mathrm{T}}-\mathrm{S}_{0}>0$ \\
Capital gain on put & $\mathrm{S}_{0}-\mathrm{S}_{\mathrm{T}}-\mathrm{P}_{0}$ & $-\mathrm{P}_{0}$ \\
Net Capital Gain & $-\mathrm{P}_{0}$ & $\mathrm{~S}_{\mathrm{T}}-\mathrm{S}_{0}-\mathrm{P}_{0}$ \\
\hline
\end{tabular}

Note: Shares and put option purchase at date 0 for $\mathrm{S}_{0}$ and $\mathrm{P}_{0}$ respectively. Option expiry and share sale (for $\mathrm{S}_{\mathrm{T}}$ ) at date $\mathrm{T}$.

As the last row of Table 3 indicates, this is equivalent to the option premium being deducted from capital gains on the shares, which are assumed to be zero if $\mathrm{S}_{\mathrm{T}}<\mathrm{S}_{0}$, because of the protection element.

The Federal Court judgement implies allocating the put option cost $\left(\mathrm{P}_{0}\right)$ as an expense over the period 0 to $\mathrm{T}$ rather than it being deducted from capital gains at date $\mathrm{T}$ as implied in the last row of Table 3. (The capital gains on the facility would under this approach be 0 if $\mathrm{S}_{\mathrm{T}}<\mathrm{S}_{0}$ (because of the protection element) and $\mathrm{S}_{\mathrm{T}}-\mathrm{S}_{0}$ if $\mathrm{S}_{\mathrm{T}}>\mathrm{S}_{0}$ ). This treatment is advantageous for the taxpayer because it involves forgoing the tax benefits of a capital loss of $\mathrm{P}_{0}$ at date $\mathrm{T}$ but receiving the tax benefits of an expense of $\mathrm{P}_{0}$ over the period 0 to $\mathrm{T}$. There is thus a present value effect (from bringing forward tax deductions) as well as the benefit from converting capital losses into expenses which are subject to a different tax treatment. (Only 50 per cent of net capital gains are included in assessable income).

To illustrate the anomaly in the tax treatment arising as a result of the Federal Court judgement, consider a simple one-period example. Let the price of the put option implied in the CPEP be $P$, and the investor's marginal tax rate be $t$. Also assume for simplicity that the 'pure' interest rate is zero. This assumption does not change the nature of the conclusions, but underestimates the benefit arising to the investor because it ignores the present valuing effect. Assume that 50 percent of the capital gain on the asset is taxed at the investor's marginal rate and that capital losses are immediately off-set against capital gains and 50 percent of the net capital gain taxed. 
The Federal Court approach implies that the tax deduction for the protection cost is $t P$. The Protective Put approach implies that the tax deduction is $0.5(\mathrm{tP})$ so that the treatment implied by the Federal Court judgement is advantageous for the taxpayer. Incorporating non-zero 'pure' interest charges would not affect the result as they have the same tax consequences under both approaches.

For the parameter values given in Table 2 the up-front cost of a three year put is 17 percent of the loan amount (that is, $\mathrm{P} / \mathrm{S}=0.17$ ) when complete capital protection is provided - such that the strike price on the put $(\mathrm{K})$ equals the loan amount (S). The tax savings for the individual are given approximately by $0.5(\mathrm{tP})=0.5(\mathrm{t})(0.17 \mathrm{~S})$. For a $\$ 100,000$ loan and an individual on the top marginal tax rate $(\mathrm{t}=0.47)$, the tax savings are $\$ 4026$. If the timing differences are also considered (with tax deductions for expenses occurring earlier than for capital losses) the present value of the tax savings is even greater.

\section{Government Response to Federal Court Judgement}

Prior to the Federal Court judgement, the Australian Tax Office had adopted an approach regarding the tax treatment of CPEPs outlined in Australian Tax Office Media Release Nat 99/26 which stated:

ATO View On Capital Protected Products: The Tax Office will disallow a proportion of tax deductions for interest claimed by taxpayers who use capital protected equity loan products to purchase shares, Tax Commissioner Michael Carmody said today.

Subsequently, particular interest rate values were specified as allowable interest expense, with the remainder of the 'quoted' interest rate effectively treated as a put option premium and a capital item. The details are set out in ATO (2001).

Commencing 18 May 2001, the previously agreed benchmark interest rate will no longer govern the amount of interest that a taxpayer will be permitted to claim in respect of capital protected equity products ... .

... For products with an agreed separately identifiable put option, the maximum deductible amount would be the lower of the Reserve Bank Bulletin Indicator Lending Rates for personal unsecured loans or 80 per cent of the total amount charged on 3 year products or 85 per cent of the amount charged on 5 year products. In the 3 year products, 80 per cent of the total interest charged would be deductible and 20 per cent would not be deductible, whilst in the 5 year products, 85 per cent of the total interest rate charged would be deductible and 15 per cent would not. The undeductible portion attributable to the put option would form the cost base of an asset for CGT purposes.

On 16 April 2003, the Federal Treasurer announced that the Income Tax Assessment Act 1997 would be amended to resolve the problems raised by the 
Federal Court decision (Australian Treasurer, 2003; ATO, 2003). Some part of the cost of any CPEP would be regarded as an interest expense and some part as payment for the protection component. An interim approach, involving an apportionment as outlined above by the ATO has been in place since that time.

The ATO approximation to the apportionment of interest and capital protection expenses can be used to calculate and compare the implied value of the put option component with option pricing model values for various crucial parameter values. Table 5 shows the combinations of $K$ (protection level) and $\sigma$ (volatility) which give equality between a modified Black-Scholes model valuation and the ATO approximation for the put value for assumed values of $r=5$ per cent or 8 per cent, a dividend yield of 4.5 per cent (hence the use of the modified Black-Scholes model), and time to maturity of $\mathrm{T}=3$ or 5 . For example, for a protection level given by K/S $=0.85$ and a risk free interest rate of 5 per cent, a volatility of 16 per cent (14 per cent) is consistent with the ATO approximation for a 3 year (5 year) facility.

Table 5: Implied Protection and Stock Volatility of ATO Approach

\begin{tabular}{l|llllllll}
\hline Panel A: $r=5 \%$ & & & & & & & & \\
Protection level (K/S) & 0.70 & 0.75 & 0.80 & 0.85 & 0.90 & 0.95 & 0.99 & 1.00 \\
Volatility (3 year facility) & 0.25 & 0.22 & 0.19 & 0.16 & 0.13 & 0.10 & 0.07 & 0.07 \\
Volatility (5 year facility) & 0.22 & 0.19 & 0.16 & 0.14 & 0.12 & 0.09 & 0.07 & 0.07 \\
\hline Panel B: $r=8 \%$ & & & & & & & & \\
Protection level (K/S) & 0.70 & 0.75 & 0.80 & 0.85 & 0.90 & 0.95 & 0.99 & 1.00 \\
Volatility (3 year facility) & 0.35 & 0.31 & 0.28 & 0.25 & 0.21 & 0.19 & 0.16 & 0.15 \\
Volatility (5 year facility) & 0.32 & 0.29 & 0.26 & 0.24 & 0.21 & 0.19 & 0.17 & 0.17 \\
\hline
\end{tabular}

For a low interest rate environment ( $r=5$ per cent) and 100 per cent protection of the share portfolio $(K / S=1)$ the volatilities that render the ATO approximation consistent with the Black-Scholes prices are too low at 7 per cent. Most individual share price volatilities for the types of stocks for which CPEPs are available are in the range of 15 to 40 per cent. This result implies that the put component value given by the approximation is too low and correspondingly the interest component too high. This will be advantageous to the taxpayer.

As the market interest rate rises, the volatilities that bring consistency between the ATO approximation and the Black-Scholes formula rise, as the figures in panel B illustrate. For a risk free interest rate (r) of 12 per cent, the share price volatilities that render the ATO approximation equal to the BlackScholes model prices are around the much more realistic level of 30 per cent.

To illustrate the magnitude of the tax benefit to the investor from the ATO approach, consider a 5-year $\$ 100,000$ facility with 100 per cent protection on a portfolio with volatility of $\sigma=30$ per cent, and a dividend yield of 4.5 per cent. If the risk free interest rate (r) is 5 per cent, the up-front value for the put option is 17.13 per cent of the value of the share portfolio, or $\$ 17,130$. The tax office 
approximation values the put option component of the facility at $\$ 3,820$. The earlier analysis of the Federal Court decision found that the benefit from treating put option costs $(\mathrm{P})$ as a deductible expense rather than a capital cost is $0.5 t \mathrm{P}$. The ATO approximation thus results in a benefit of lower tax to the (highest marginal rate, $t=0.47)$ taxpayer of around $0.5(0.47)(17,130-3,280)=\$ 3129$. If the timing effect is taken into account, the benefits are even higher.

\section{Conclusions and Policy Recommendations}

The preceding analysis has identified a number of issues relevant for determining the appropriate tax treatment of CPEPs. Fundamental to this analysis is the decomposition of a CPEP into component parts consisting of a loan, a share portfolio purchase, and a capital protection feature. Costs to the investor can be decomposed into a 'pure' interest cost of the borrowing, purchase cost of the protection feature, and a 'service' cost which reflects the CPEP provider's operating costs and profit margin.

A decomposition of the costs charged by the CPEP provider to the investor into those component costs can be done by use of finance theory. Standard techniques are available for calculating the value of the protection feature using techniques such as option pricing theory, and it can be expected that any provider of a CPEP undertakes such a valuation using option pricing modelling as part of their product analysis and pricing. Subject to approval of the assumptions and model used, there would appear to be no reason not to use the provider estimates of the value of the protection facility for tax purposes. A broad range of acceptable assumptions and models could be listed by the ATO for use by CPEP providers in calculating the protection component cost for investor tax purposes thus avoiding a need for specific product rulings in most cases.

Investors need such information for taxation purposes and for informed decision making should be aware of the market value of the protection component. Hence it would seem appropriate that such information should be contained in product disclosure documents. One complication which arises here is that such calculations of option prices are based on an assumption of no transactions costs and ability to replicate the option by transactions in the underlying instrument. While such estimates reflect the cost of providing such an option by a wholesale financier (such that sale at that price gives a net present value of zero), they can significantly underestimate the value of such an option to a retail investor, who cannot replicate the option. While market competition may drive the price explicitly or implicitly charged to retail investors down towards the wholesale 'fair market value', it is likely that the price charged to investors makes sale of the option a positive NPV transaction for the provider.

As shown earlier, the appropriate 'pure' interest rate to charge for a CPEP is a risk free interest rate (or one equivalent to the cost of debt financing by the provider) if the protection level is set at the initial share portfolio value (100 per cent protection). In such cases, 'default' by the borrower on the non-recourse loan is equivalent to exercise of the put option, for which an appropriate charge has 
been included in the total costs. The 'default risk' is in fact the 'market risk' borne by the CPEP provider via the option component for which a charge is implicitly already levied.

A protection level of less than 100 per cent could arise in two ways. The first is where the investor has contributed some own funds towards purchase of the share portfolio and the protection level is set equal to the amount lent by the CPEP provider. (Instalment warrants are an example of this type of arrangement). In this case, the appropriate 'pure interest rate' is again the risk free rate, for the same reasons as outlined above. The second possibility is that the loan amount is higher than the protection level set. Here the CPEP provider does face some real default risk, but only on that part of the loan in excess of the protection level. It is possible to estimate the appropriate credit spread on that part of the loan and thus the appropriate 'pure interest rate' for the total loan, although it depends upon both the probability of the investor defaulting and characteristics of the share portfolio and protection level. Realistic assumptions indicate that the appropriate 'pure interest rate' is significantly less than the rate appropriate for unsecured personal loans.

It is the third component of the total charges to investors for CPEPs which is perhaps the most difficult to isolate and estimate. Total charges must cover operating costs and a profit rate as well as lending costs and protection provision costs. That profit rate needs to be adequate for the risks involved in the business, but is potentially significantly higher if market competition is limited and investors are unaware of the true value of, or unable to replicate, CPEPs, such that they earn above normal profits for the provider. However, once lending costs and protection costs have been estimated as outlined above, this third component can be calculated as the residual component of the total charges levied.

Whether this third component should be viewed as an expense item or a capital item for investors is a moot point, and the decision made in that regard perhaps dictates the appropriate approach for policy. If it is viewed as being a capital item, then it may be appropriate for tax policy to involve calculation of the 'pure interest' component and allow the remaining costs to be treated as capital costs. Alternatively, if it is viewed as an expense, then calculating the cost of the protection component and allowing the remaining costs to be treated as an expense item may be appropriate. A further option could be to require calculation of both 'pure interest' and 'protection costs' and pro rata the residual costs between expense and capital items.

At a more general level, there appears to be a case for a more fundamental reconsideration of the tax treatment of financial instruments offering contingent payoffs (as suggested by Bradford, 1997). The analysis of this paper has taken as given the current tax treatment applied to capital gains, which gives rise to the opportunities for tax arbitrage generally, and through development of products such as CPEPs. The suggestions advanced in this paper are based on making the tax treatment of CPEPs consistent with the tax treatment of the underlying products, and thus not providing even greater rewards to tax arbitrage. 


\section{References}

Assistant Australian Treasurer (2003), 'Taxation of Capital Protected Products', Assistant Treasurer's Press Release No. 46 of 2003, 30 May, http://assistant.treasurer.gov.au/atr/content/pressreleases/2003/046.asp.

Australian Tax Office (2001), 'Benchmark Interest Rates for Capital Protected Equity Products', 8 November.

Australian Tax Office (2002), 'Product Ruling: Income Tax: Tax Consequences of Investing in Macquarie Instalment Warrants - Cash Applicants and on-Market Purchasers', PR 2002/90, http://law.ato.gov.au/atolaw/view.htm?find= per cent22 macquarie per cent22\&docid=PRR/PR200290/NAT/ATO/00001.

Australian Tax Office (2003), 'Tax Office Acts on Capital Protected Products', ATO Media Release NAT 03/51, 30 May.

Australian Tax Office (2005a), 'Taxation of Capital Protected Products', 8 March, http://www.ato.gov.au/print.asp?doc=/content/52483.htm.

Australian Tax Office (2005b), ‘About Capital Protected Products', 12 January http://www.ato.gov.au/individuals/content.asp?doc=/content/44515.htm.

Australian Treasurer (2003), 'Taxation of Capital Protected Products', Press Release No. 19, 16 April, http://www.treasurer.gov.au/tsr/content/pressreleases/2003/019.asp.

Black, F. and M. Scholes (1973), 'The Pricing of Options and Corporate Liabilities', Journal of Political Economy 81:637-54.

Boadway, Robin and Michael Keen (2003), 'Theoretical Perspectives on the Taxation of Capital Income and Financial Services: A Survey', http://siteresources.worldbank.org/DEC/Resources/23652_Chap_2_taxation.pdf.

Bradford D. (1997), 'Fixing Capital Gains: Symmetry, Consistency and Correctness in the Taxation of Financial Instruments', Working Paper 5754 National Bureau of Economic Research, http://papers.nber.org/papers/w5754.pdf.

Federal Court of Australia (2002), 'Federal Commissioner of Taxation v Firth [2002] FCA 413 Hill, Sackville and Finn JJ', Federal Court of Australia 17 April 2002 — Sydney, http://law.ato.gov.au/atolaw/view.htm?locid='JUD/50ATR1.

Merton R. (1974), 'On the Pricing of Corporate Debt: The Risk Structure of Interest Rates', Journal of Finance 29:449-70.

The authors gratefully acknowledge the helpful suggestions of the Co-Editor, Graeme Wells and two anonymous referees. A working paper containing technical derivations is available on request from the authors. 